\title{
RESPONSIBLE BEHAVIOR AND ENVIRONMENTAL PROTECTION - IN CASE OF FOOTBALL CLUBS
}

\author{
Kinga Ráthonyi-Ódor, ${ }^{1}$ Éva Bácsné Bába, ${ }^{2}$ Gergely Ráthonyi ${ }^{3}$ \\ ${ }^{1,2}$ Department of Sporteconomics and Management 4032 Debrecen, Böszörményi 138. \\ ${ }^{3}$ Department of Agricultural Informatics 4032 Debrecen, Böszörményi 138. \\ E-mail: rathonyi-odor.kinga@econ.unideb.hu \\ bacsne.baba.eva@econ.unideb.hu \\ rathonyi.gergely@econ.unideb.hu
}

\begin{abstract}
There has been a hotspot in sports industry these days that is becoming more and more wide-spread in sports organizations and among managers, namely CSR, that is corporate social responsibility. In the life of geographical regions, towns or villages, professional football clubs play a crucial role. Consequently, clubs tend to take responsibility for these communities in return for their support: whether it is the local population or the authorities, other businesses or the environment, they are ready to stand up for good causes. Nowadays sports centres with their regular events have a significant effect on the environment either regionally or globally. That is the reason why it has become vital in the management of sports facilities to respect environmental principles when designing and using sports facilities and to avoid producing pollution that could harm and deteriorate the environment. The aim of our study was on the one hand, to present the definitional and theoretical evolution of CSR, than the CSR concept in sport, special regard to environmental protection. On the other hand, to analyze what kind of CSR related issues do football clubs (Real Madrid C. F. - RM, Borussia Dortmund - BVB) and how they are addressing issues of environmental sustainability in the context of CSR. According to RM and BVB, we can say that they really try to do efforts to responsible behavior and environmental protection. They have special respect for the society and took big step to use different environmental management tools. It was easy to find information, reports and case studies about these activities.
\end{abstract}

Keywords: football clubs, environmental protection, responsible behavior (JEL Classification: M14)

\section{INTRODUCTION}

Over the last 50 years, research on the area of business and society has tried to identify the points of linking between corporate strategies and societal demands (KOLYPERAS, 2012).

According to DAVIES and MOYO (2017) CSR is a growing interest and is seen as one of the key areas of sustainability for corporate businesses.

According to international studies (COSTA, 2017; KOLYPERAS, 2012; PORTER and KRAMER, 2006) there are four acceptance of the CSR concept in the business world:

1. Business organizations have become more aware of the impact of their actions due to public responses on issues they had not previously thought and/or addressed.
2. CSR is conceptually grounded on the notion of sustainability. The concept of sustainability is even more popular through the years: environmental sustainability and social sustainability CSR could be a sustainable-related tool whose purpose is to create shared value and lead to self-sustaining solutions.

3. CSR is justifiable from a legal perspective.

4. CSR does not only have philanthropic values, but is also profitable as far as business is concerned. At first glance, CSR appears to be a "return gesture”, however lots of organizations see it as a strategic opportunity. That is to say, CSR is considered as an interactive tool counteracting scandals quickly spread in the media and as a result of that, public scepticism. 
In the point of our view, CSR is a sustainable-related tool. With the help of this, companies can also protect the environment or satisfy the societal demands.

The socially responsible approach of a firm can be manifested through its actions, which can be in the field of sports growing more and more in popularity (SCHEINBAUM and LACEY 2015). The circle of international studies in the area of sports science has been broadening in the past few years that are looking into the spread of CSR activities of sports organizations (companies, clubs) and the CSR provisions of non-sport corporatations in the field of sports, or analyse the CSR initiatives of large-scale sports events (DJABALLAH et al. 2016; DOWLING et al. 2013; FLÖTER et al. 2016; INOUE et al. 2011; RÁTHONYI et al. 2016a; RÁTHONYIODOR and RÁTHONYI 2016b; TRENDAFILOVA et al. 2013).

In Europe one of the most popular sport entertainment activity is the football, with a high potential for future development (BLUMRODT et al. 2013).

More and more researchers have emphasized that professional sport teams have single resources available to them to deploy their CSR programmes and generate maybe greater awareness for social and environmental issues than businesses in other industries.

In this study the CSR practice of Real Madrid C.F. and Borussia Dortmund has been studied. We wanted to analyze two top European clubs which latest CSR reports are available.

In our study we try to answer the following questions that our paper can articulate:

1. What CSR means from an analyzed sport club perspective?

2. What kind of CSR related issues do football clubs?

3. How football clubs try to integrate environmentally friendly activity in their movement?

\section{LITERATURE REVIEW}

\section{Definitional and theoretical evolution of CSR}

The idea of CSR dates back to the early 20th century when business colossuses, such as Ford, started to donating funds in order to develop social conditions.

After the industrial revolution CSR grew in popularity in modern societies, especially towards the late 1960 s, when business corporates were confronted with a rising public activism and sceptic views as for their responsibility and share in social matters and injustices (CLARK, 2000).

According to VAN MAARREWIJK (2003) CSR means something but not always the same thing to everybody. As a result, numerous definitions and theories have been brought to bear on the matter of CSR.

In the 1930s, DODD argued that managers and corporations have certain responsibilities to society (NILSSON, 2018).

In 1953 BOWEN tried to define CSR in his book „Social responsibility of the businessman". He suggested that CSR refers to "the obligations of businessmen to pursue those policies, to make those decisions, or to follow those lines of action which are desirable in terms of the objectives and values of the society (FILIZÖZ and FISNE, 2011).

In 1960 DAVIS defined CSR as „the firm's consideration of, and response to, issues beyond the narrow economic technical and legal requirements (CAROLL and BROWN 2018, 45.p.)".

The 1970s were marked by a strong debate on the importance of CSR for business. Milton Friedman stated that firms have only a premium responsibility to their direct investors, that of maximizing profit and that the mere existence of CSR was a signal of an agency problem within the firm (WATSON and PREVOS 2009).

At the end of the 1970s, CAROLL's model and articulation became one of the most frequently-cited CSR models. $\mathrm{He}$ synthesized previously conducted research with the definitions offered earlier into what he observed as the four 'facets' of CSR; economic, legal, ethical, and discretionary responsibilities.

Another classic definition of CSR made by SETHI (1975), which made a three dimension framework of corporate behavior, dividing it in social obligation, social responsibility and social responsiveness. On the other hand, FRIEDMAN (1970) claimed that CSR and business were two completely distinct areas that should not mix, as it is not the duty of business to solve social issues instead of the government (COSTA, 2017).

During the decades of 1980s and 1990s, the definitional development of CSR was marked by two lines of thought. One of them was engaged in efforts to define the relationship between CSR and profitability. The other used stakeholderbased manifestations of CSR (KOLYPERAS, 2012).

CSR became a factor among the duties of the European Commission in the 1990s. The Council of Ministers in the 2000 Lisbon meeting agreed that companies should take steps for the sake of sustainability in their closer or wider surroundings. Eventually, in 2001 the European Union articulated its provisions taking CSR into account, which was also framed in the form of a green publication entitled „Promoting an European Framework for Corporate Social Responsibility“ (HEGELOW, 2015).

For the EUROPEAN COMMISSION (2001), CSR is a program where companies decide voluntarily to contribute to a better society and cleaner environment. It is seen as an option where, along with their prime responsibility of generating profits, companies can contribute to social and environmental objectives, through integrating corporate social responsibility as a strategic investment into their core business strategy, their management instruments and their operations.

The definition above, is quite close to the academics' definition in which CSR is defined as the responsibility of an organisation to be ethical and accountable to the needs of their society (BLUMRODT et al. 2013).

The WORLD BUSINESS COUNCIL FOR SUSTAINABLE DEVELOPMENT (WBCSD) (2002) defined CSR in general terms as the continuing commitment by business to behave ethically and contribute to economic development while improving the quality of live of the workforce.

BUSINESS COUNCIL FOR SOCIAL RESPONSIBILITY 
(2004) writes the following: it is about a kind of business practice that exceeds ethic, legal and commercial expectations formed and set against ventures by the public (BCSR 2004). When defining the concept, the establishment puts an emphasis on the fact that the accountable actions of a company exceed the attempt to meet the requirements of public opinion. Values - balance, social and financial missions - must stand on the first place of a companies goals.

The various definitions are common in the respect that a healthy and sustainable balance should be created between economic interests, social expectations and environmental limits in the course of business.

\section{Corporate social responsibility in sport}

With the rise of environmental consciousness, environmental issues have become valued and mainstream. Many sport organizations, sport clubs are concerned with the effectiveness of adopting green management tools and green marketing strategies (HUANG et al. 2014; PAPASPYROPOULOS et al. 2012). The environmental management tools may be an important step towards sustainability and the preservation of environmental values. According to these environmentally responsible business practices (e.g. energy, waste and pollution reduction, decreased use of toxic materials), are element of CSR.

It has been long and widely accepted that sport has particular relevance to both the impact and power it has with respect to its CSR-related practices (SMITH and WESTERBEEK 2007).

Regarding sports management, CSR is the equivalent of sustainable development at business level. This notion standsat the intersection of three pillars: economic, social and environmental (ROBERT and DELHEZ, 2015).

Both sports organizations and corporates have become aware of their accountability in social questions: sports associations emphatically deliver social values, focus on physical health, improved education, social interaction and pro-environmental actions, whereas corporates also make huge efforts to be socially beneficial in the professional sports industry and through related organizations.

There are several prevalent types of CSR-related practice throughout the professional sport industry, which can be conceptually divided into three categories (KOLYPERAS, 2012):

1. the CSR activities made by sport organization and entities (action of leagues, teams, mega-events or individual athletes);

2. CSR and sport-related foundations, where CSR is a product of partnerships between different organizations and delivered independently by non-for profit organizations;

3. CSR activities made by by sport-related companies and often executed via sports.

Our study joins to the first access.

SMITH and WESTERBEEK (2007) present seven features to use sport as a vehicle for deploying CSR. These features are as follows:

- The popularity and global reach of sport can ensure that sport CSR has mass media distribution and communication power.

- Sport CSR has youth appeal. Children are more likely to engage in a CSR program if it is attached to a sport organisation or a sport personality.

- Sport CSR can be used to deliver positive health impacts through programs and initiatives designed around physical exercise.

- Sport CSR will invariably involve group participation and therefore aid social interaction.

- Sport CSR can lead to improved cultural understanding and integration.

- Particular sport activities may lead to enhanced environmental and sustainability awareness.

- Participating in sport CSR activities can provide immediate gratification benefits.

Features above related to social and environmental aspects of CSR. Within social aspect we can work up 4 categories: (1) educational programs, (2) sport/health programs, (3) social/ cultural programs and (4) charity programs. We strongly agree with NILSON $(2018,19$. . $)$, who suggest that „social sustainability means the provision of equal opportunities, diversity in the workforce, connections to the surrounding community, ensuring of life quality and democratic processes".

In line with environmental aspect we can see, that environmental sustainability increasingly recognized as a central aspect of CSR, is important not only for recreational sport firms, but for all sport organisation (JENKINS, 2011).

\section{Environmental values in sport}

Academic work are focusing on sport and the environment has steadily grown over the past 15 years (TRENDAFILOVA et al. 2014).

On the one hand sports by their very nature bring people together; athletes, spectators, officials, sponsors and suppliers come together to participate in and support sport.

On the other hand, all sports use natural resources in some measure and have an impact on natural environment. Sport is claiming more territory and endangering natural landscapes A number of animal and plant spieces are dying out, enormous amounts of water is polluted causing environmental hazards. In addition, applying non-renewable materials, the refuse emission in the building and operation process of sports facilities, shuttling to and from these places, catering, health care provisions, commercialism, producing and the disposal of sports equipment multiply the causes that can and should be helped by CSR (BRAR and PATHAK 2016; RÁTHONYIODOR and RÁTHONYI 2016; SHIPLY 2018).

It is undoubted, that sport is a substantial enabler of sustainable development (GIULIANOTTI et al. 2018). Sport receive a great popularity in modern society (DENG and ZHOU 2017). Even more sport related bodies have been pioneering in new strategy for integration of the environment in business strategy (MOGHADDAM et al. 2018).

According to SHIPLEY (2018), to making sport greener, it is needed that: 
- representatives of sport and those promoting nature conservation and environmental protection;

- join forces and draw up guidelines for sustainable development in sport;

- promote and further develop forms of sport which are compatible with nature and the environment;

- make sports-related infrastructure more environmentally compatible;

- strict compliance of environmental standards by government and agencies funding sports facilities;

- incorporate environmental management into the work of sports administration, clubs, associations and commercial sports operators;

- voluntary commitments should be given priority for achieving conservation aims.

\section{MATERIAL AND METHODS}

In the conceptual clarification of corporate social responsibility, the presentation of CSR concept in sport special regard to environmental protection - we relied on international and Hungarian special literature (BLUMRODT et al. 2013; KOLYPERAS, 2012; JENKINS, 2011; MOGHADDAM et al. 2018; NILSSON, 2018; RÁTHONYIODOR and RÁTHONYI 2016; SHIPLEY, 2018).

To analyze what kind of CSR related issues do football clubs (Real Madrid C. F., Borussia Dortmund) and how these clubs are addressing issues of environmental sustainability in the context of CSR, we applied a comparative analysis based on secondary databases. We compared clubs' CSR activity, environmentally conscious behavior with the help of data gained from their web sites, reports, case studies (BVB, 2018; ESTERLUSS, 2017; INTERNET 1,2,3,4,5,6,7,8; RM, 2018).

We chose these clubs, because they have sustainability report (including social/environmental sustainability) in English, which contain detailed information about analyzed topic and they are front-rang clubs.

\section{RESULT AND DISCUSSION}

\section{Responsible behavior by Real Madrid C. F.}

RM was founded on 6 March 1902 as Madrid Football Club. The team has played its home matches in the 81,044-capacity Santiago Bernabéu Stadium in downtown Madrid since 1947. The club was estimated to be worth $\square 3.8$ billion ( $\$ 4.2$ billion) in 2019, and it was the highest-earning football club in the world, with an annual revenue of 0750.9 million in 2018. More than 200 people worked on a daily basis on Real Madrid Sports City, although at certain times this figure reached 500 .

In order to present Real Madrid C. F. (RM) CSR and green activity, we analyzed the club's 34 pages long Corporate Social Responsibility and Sustainability Report (2017-2018) and some related articles, case studies.

In the first chapter we can read about e.g. institutional profil, misson, vision, corporate governance, transparency policy and values. Among values, we can find what social responsibility means for the club: „Real Madrid is aware of the high social repercussion of its activities. It therefore dedicates all the resources within its power to complying with the very highest standards of good corporate governance and the promotion of the best sporting values, to strengthening its relations with its members, former players, fan clubs and supporters, and to the development and implementation of solidarity projects in favour of the needy both within Spain and beyond its borders (RM, 2018 4.p.)."

In the second chapter, named RM Corporate Social Responsibility, the report mentioned stakeholders served by RM (e.g. members, players, referees, employees, supporters, suppliers, other club, media, society) and their relationship and activity.

The next chapter is about fulfilment of commitments in 2017-18. In this part of the report CSR related issues are detailed presented. We briefly interpret issues 1-8 with help of some examples, then we focus on environmental protection (RM, 2018).

1. social sports schools in Spain; They emphasise that, according to their mission education in values through sport continues to be the main vehicle of social action. In their Football and Basketball social sports they promote healthy lifestyles, sport as a beneficial way for children to spend their leisure time and to collaborate with families to provide all-round training for more than 6.000 children aged between 5-17, in a total of 65 social sports schools. They provide different programmes e.g.:

- The club participated in a number of inclusive days: in the International Disability Day, World Autism Day.

- During the season, more than 300 international clinics were held in 43 countries on all five continents, with more than 40.000 children and young people participating. Additionally, 177 of these clinics were held at Real Madrid City, which welcomed more than 5.000 players from over 35 countries.

2. social-sports projects with other groups at risk of exclusion; The inclusion of the Homeless People group among those benefitting from Real Madrid Foundation's activities is one of the milestones of the last season. Three training groups were set up in partnership with Spanish Red Cross, Madrid City Council and the P. Garralda Foundation. This new scheme assists more than 50 adults with the aim of helping them to recover their mental wellbeing. Last year they organised 22 football and 21 basketball projects involving 2.500 inmates to contribute towards their re-education and their reintegration into society. It also provides care for groups in Hospitals, Prisons, Shelters and Detention Facilities, where values are taught that will accompany the participants throughout their lives (INTERNET 3).

3. the international area of the RM foundation; Last season, the Foundation's international programmes, working in partnership with some of the major children's NGOs, have continued their process of consolidation, undertaking altogether over 300.000 hours of sporting value related activities through nearly 2.000 working groups, 800 teacher-trainers in 300 projects in 76 countries. More 
than 39.000 girls, boys and young people who, as well as learning about sporting values thanks to these schools, also receive medical assistance, food and schooling, and over 200.000 hours of social assistance each year.

4. communication, events and institutional activities; The Real Madrid Foundation's 20th anniversary has been marked by a full season of special events. E.g.: After the traditional Christmas campaign, the New Year began with the Foundation's 2nd Popular Race in Madrid, in which 6.000 runners took part. From month to month, interesting cultural and sport programmes were heled by the Foundation.

5. veterans, ambassadors and RM icons appearances; Ambassadors for Real Madrid, including Roberto Carlos and Julio Baptista, participated in the Luis de Carlos Forums and in promoting the Foundation's charity events. The ambassadors taking part in the 2nd Charity Race were Raúl and Arbeloa. Julio César became the ambassador for the programme of clinics in Brazil, Iván Helguera visited their project in the Dominican Republic and once again, Pepe Salguero supported the Churriana Tournament for the schools in India.

6. players appearances; The students attending the international schools who visit Madrid, have the opportunity to say hello to the first team players in a short meeting, which fills them with enthusiasm, motivating them to continue with their efforts. Players visits to young people with serious illnesses weekly. Marcelo visited to the schools tournament being played at RM City on his birthday.

7. publications, prizes, speeches and forums; In the analysed season, the RM Foundation became more widely involved in academic and international forums in the industry, such as the World Football Summit, Football is more; in conferences about team sport and autism at the European University; taking part in the United Soccer Convention, the 4th FIFA Congress on social actions. It has been awarded a number of prizes such as the 2017 Childhood Recognition award from the Madrid Regional Government, the Montevideo Cervantes School award, the Nine Values Cup, the Olavidia Heart prize, the YPO Latam Best Business Foundation award.

8. RM Graduate School European University activities; The school is present in 12 countries: Spain, Costa Rica, Ecuador, Mexico, Chile, Colombia, Brazil, Peru, Germany, Portugal, United Kingdom and Australia. Focusing on the areas of health, sport, management and communications, their school offers 15 master's degrees (INTERNET 1).

Next, we would like to present how RM try to integrate environmentally friendly activity in their movement.

In the 2017/2018 season, RM has continued to develop its environmental protection policy as a key component of its sustainability strategy. This season they would like to get an audit of the environmental impact of RM's entire business, a measurement of the carbon footprint of the club's operations and the introduction of other scientific methods to assess their impact on the environment. Real Madrid's environmental agenda includes material and waste recycling, energy generation and consumption, water usage and treatment, greenhouse gas emissions into the atmosphere and the planting of trees, sports pitch turf and ornamental plants.

We would like to present some of the club green activity (RM, 2018):

- More than 200 new trees have been planted and chemical products are no longer used in the maintenance of the garden areas, including a drastic reduction in the use of fungicides on the natural grass football pitches. They continue the replacing combustion-engine powered garden machinery with electrical equipment.

- Since 2007, RM has had an agreement with Ecoembes Spain, S.A. for the of selective collection and recovery of light containers and cardboard at the Santiago Bernabéu Stadium and at Real Madrid City, through which a system has been set up for the collection, transport and subsequent treatment of waste. Under this agreement, in the $2017-2018$ season, some $617.170 \mathrm{~kg}$ of waste was collected, of this amount $86.31 \%$ constitutes recyclable lightweight containers, paper and cardboard.

- Through such recycling, they managed to reduce energy and water use, as well as cut greenhouse gas emissions into the atmosphere. This efficient management of lightweight container waste has enabled them to save: 41 tonnes of $\mathrm{CO} 2$ emissions (equal to the emissions produced by 121 vehicles), $392.430 \mathrm{KWh}$ of electrical energy consumption (equivalent to the annual consumption of 121 homes), 9.283,107 litres of water (equal to the daily consumption of 65.374 people).

- During the 11 years of the agreement with Ecoembes, more than 4.698 tonnes of light containers and 1.340 tonnes of paper and cardboard have been recycled.

- During the last season, 260 waste separation bins and containers have been installed in the VIP Area in the Stadium, 145 with three compartments and 115 with two compartments.

- 22 new, electrical powered cleaning machines have been introduced, thus eliminating the storage and use of fossil fuels and almost completely eliminating noise pollution during their use.

- They reduced their daily purchase of the printed press, replacing it with digital publications (from 6.179 per month to 2.350).

- In 2016 RM has conducted an Energy Audit of all its buildings, all of which have passed successfully. We mention just some of their implemented measures: LED technology in emergency lighting for stands and buildings; there are motion sensors in public toilets in the stadium and RM City; installation of chargers for electric vehicles at the new corporate office building; installation of frequency inverters in both pumping equipment and in air-conditioning fans.

- RM planed to upgrade the Santiago Bernabeu (stadium of RM) by 2022 at a cost of 4525 million was given the green light (INTERNET 4).

- They have the guarantee certificate for the source of its electrical power supplies. $100 \%$ of the KWh purchased 
for their buildings was previously generated by renewable energy sources (principally solar and wind energy).

- The entire annual water consumption of their football pitches and ornamental gardening of the Real Madrid City comes from the recycled water network of the Madrid City Council.

- Heat recovery systems and CO2 level sensors permitting the use of the ventilation systems only when absolutely necessary have been installed as well as lift installations with frequency variators and quadruplex calling to save waiting times and permitting shorter lift journeys.

- All lighting in the building is controlled by movement sensors, light intensity sensors or by timed programmes, meaning that no lighting is left on when it is not required.

- They encourage the use of electrical vehicles with the installation of 6 recharging points in the new building car park.

- The new office building has a certified energy consumption of $241 \mathrm{KWh} / \mathrm{m} 2$ per year and gas emissions of just $41 \mathrm{Kg} \mathrm{CO} 2 / \mathrm{m} 2$ per year, with $100 \%$ being generated by renewal energy sources.

- The new uniforms of Adidas for 2018-2019 for Real Madrid are made of plastic rescued from the oceans (INTERNET 2).

All these measures have led to Real Madrid being awarded the STMA - Sports Turf Management Association environmental certification with validity until 2020 .

In the additional part of the report, we can read about the financial performance of RM.

According to RM, we can say that they really try to do efforts to responsible behavior and environmental protection. They have special respect for the society and took big step to use different environmental management tools. It was easy to find information, reports and case studies about these activities.

\section{Responsible behavior by Borussia Dortmund}

Borussia Dortmund is a German sports club based in Dortmund, North Rhine-Westphalia. Founded in 1909 by eighteen football players from Dortmund, the football team is part of a large membership-based sports club with more than 145,000 members, making BVB the second largest sports club by membership in Germany. In October 2000, Borussia Dortmund became the first publicly traded club on the German stock market.

To introduce BVB CSR and environmentally friendly activity, we analysed the club's 67 pages long Sustainability Report for the 2017/18 season and some related articles.

In the first part of this report we can read about how they celebrate on the match day, structured development (e.g.: sustainability context, organisational structure, stakeholder dialogue,), challenges and new beginnings (e.g.: sustainability and the stadium, holistic HR development, product quality and service) (BVB, 2018).

The second part of the report deals with social and environmental responsibility and the financial performance.

Social responsibility focuses on three topics: (1) fans and club members, (2) employees and (3) product responsibility. Next, we would like to demonstrate some related activity (BVB, 2018).

1. Fans and club members:

They emphasize, that BVB focuses on actively fighting discrimination and promoting the diversity of its fans. BVB stands firmly against right-wing extremism and discrimination and supports BVB fans with the same attitude (just 13 criminal acts and 111.000 euros in fines during the last season).

By Borussia Dortmund was formed the "leuchte auf" foundation in 2012 which is an independent charitable organisation. Its objective is to support charitable projects, either through financial or intellectual contributions. 273.958.76 euro donations received in the last season and 31 projects were supported. For examples: "leuchte auf" funds playground equipment for primary school children (INTERNET 6), "leuchte auf" supports campaign for road traffic safety (INTERNET 7).

In 2019 the club provides new training program for heavyweight football fans. The entire, free 12-week course aim is for overweight BVB fans to get into better shape and accordingly increase their quality of life (INTERNET 5).

\section{Employees}

The report mentioned that social and humanitarian responsibility, health and safety are also economic factors that are important for keeping their employees motivated. In 2018 , the club hired a company physician who, in addition to providing basic medical care, also offers occupational medical advice and helps develop measures to promote employee health. E.g.: they offer all employees the opportunity to receive flu vaccinations.

Beginning with the 2018/2019 season, BVB employees have free access to a gym.

BVB offers an individualised internal and external continuing education programme to its employees. For instance, they worked together with the educational centre of their sponsor, WILO. The club offers training in 11 professions, not only those that are typical for the industry, but also in areas which are not so typical for football clubs. The club also offers its employees various levels of Englishlanguage courses.

\section{Product responsibility}

This chapter deals with spectator safety, stadium/service quality and product safety/quality.

In April 2018, their security staff members underwent the most extensive security training programme. Other related measures include the establishment of their own entry control system and the creation of the position of full-time security manager by the start of the 2018/2019 season. In this season additional security gatehouse and further separating lanes had been completed in the entrance areas as well as improvements to the radio and camera systems and the fence system on the stadium's outer boundary (BVB, 2018).

The concrete paving of the lower tier of the stadium's west terrace marked the completion of a maintenance cycle 
for all lower tiers. This work was implemented as a safety measure to protect the structural integrity of the stadium and, by extension, the spectators.

They had a large number of investments to reduce the waiting time for visitors: 1.125 service staff attend to their visitors on match days: VIP and hospitality catering (380), public areas (500), kitchens and buffets (185) and logistics/ supervisors (60).

They directly improved the experience for the more than 120.000 stadium tour visitors by introducing multi-language audio guides.

Hermes Hansecontrol subjected all products (sports equipment, electric tools, IT equipment), to testing in accordance with European standards and laws to ensure that their products do not contain hazardous chemicals. Under the revised agreement, Hermes Hansecontrol would prepare certificates of free sale, which confirm that products have been packaged and labelled in accordance with European standards, and, together with external experts, carry out a risk assessment at an early stage of the product development phase for new products (BVB, 2018; INTERNET 8).

Next, we would like to present with help of the report how BVB try to integrate environmentally friendly activity in their movement.

Within environmentally responsibility, we can get information in connection with (1) energy and emissions, (2) mobility, (3) water and wastewater and (4) use of resources

\section{Energy and emisions}

In 2011, BVB invested 1.9 million euro to install 8.768 solar panels in the form of the BVB logo across $8.300 \mathrm{~m}^{2}$ on the roof of Signal Iduna Park (training ground). In 2017, BVB fed $521.000 \mathrm{kWh}$ of green electricity back into Dortmund's electricity grid (2016: $558.000 \mathrm{kWh}$ ) - enough to power 143 three-person households with clean energy for an entire year (BVB, 2018; ESTERLUSS, 2017).

As a part of their "Strom09" energy conservation campaign, they teamed up with their electricity provider "LichtBlick" to further reduce their $\mathrm{CO} 2$ emissions and the resources we consume. By June 2016, CO2 emissions had already been reduced by 25,000 tonnes, equivalent to one tonne per standing place on the south terrace. The overall aim is to reduce carbon by 81.360 tonnes - one tonne per seat (CAMPELL, 2018). In order to use of green energy at Signal Iduna Park and the FanWelt service centre alone in 2017, they managed to reduce LichtBlick's CO2 emissions by 3.810 tonnes.

Three Dortmund-based community organisations received green energy free of charge for one year from BVB. In total, 10.000 euro was donated to the three community organisations to pay for urgently needed materials.

BVB's emissions are accounted for and classified into three categories known as scopes in accordance with the principles of the Greenhouse Gas Protocol (GHG Protocol): direct emissions from owned or controlled, indirect emissions from the generation of purchased electricity, steam, heating and cooling consumed by the reporting, all other indirect emissions that occur in a company's value chain. In the report we found detailed information about the three categories, how many tonnes of CO2 was reduced year by year from 2016 (BVB, 2018).

\section{Mobility}

An average of 79.864 spectators (2016: 79.712) travel to the stadium per match, of which just under $51 \%$ come from the VRR (Verkehrsverbund Rhein-Ruhr) transport authority region. Most of the $31 \%$ of season ticket holders walk to the stadium, some even ride their bicycles. Tickets include the fare for public transport to travel to/from matches and are valid to/from any destination in the VRR transport authority region. $43 \%$ of fans take advantage of this service.

They collected data on their vehicle fleet's fuel consumption and the number of kilometres travelled by train for business trips. They have permanently added electric car to their fleet and use it for courier services. They are also planning to use bicycles or e-bikes for travelling between the stadium, the training ground and the headquarters building.

\section{Water and wastewater}

Club uses rainwater to irrigate and water their pitches in Brackel (there is the training ground and academy). They are gradually installing water metres at individual locations in order to collect more detailed information about their water consumption and determine further savings potential. Borussia Dortmund's wastewater is routed to the city's canal system in compliance with the applicable requirements. The water used for the pitches is absorbed by the grass or evaporates; any excess water seeps into the ground.

The 20-hectare training ground has both artificial and natural grass pitches. The pitches are watered using a cistern system, which collects water that has seeped into the ground and transports it to the cisterns via a network of pipes.

They reduced the amount of fresh water by $10.412 \mathrm{~m}^{3}$ or $14.6 \%$ from 2016 to 2017 . This is approximately equivalent to the annual water consumption of around 80 three-person households.

\section{Use of resources}

They try to keep the waste they produce to a minimum and to recycling unavoidable waste.

Their aim is to achieve a high level of vertical integration in the production of prepared food in order to ensure quality and prevent food waste. They also employ an accurate and professional food management system to help their vendors in this endeavour.

Any food waste is transported $20 \mathrm{~km}$ to a nearby biogas plant for recycling.

Due to the increase in other events held at Signal Iduna Park and the significant expansion of the cafeteria menu at the Brackel training ground, the total amount of food waste 
increased by $3 \%$ to $188,5 \mathrm{~m}^{3}\left(2016: 182,5 \mathrm{~m}^{3}\right)$.

At the beginning of the new 2018/2019 season, they test a reusable cup system in the family block with the aim of rolling out a new system for the entire stadium at the beginning of the 2019/2020 season.

Dortmund has installed 200 special tubes into which fans can chuck their cups instead of simply throwing them on the floor (ESTERLUSS, 2017).

In total, the club produced 448 tonnes of waste, $20 \%$ less than in 2016 (554.0 tonnes) (BVB, 2018).

According to BVB, we need to say, that the club is commitment with the responsible behaviour for the society and the environment.

The report presents detailed information about their CSR activity, we can read about their concept and objectives, related measures and results. They also have wide range of activity to support the different part of the society.

They are used state-of-the-art technologies to make their activity greener and introduce these with full particulars.

\section{CONCLUSION}

Sport can contribute to the effectiveness of sport-related CSR programs, including environmentally conscious attitude, the generation of greater awareness of social problems, an ability to effectively contemplate the ethical side of sport and its respective organizations.

We agree with JENKINS (2011), that the natural environment is increasingly being viewed as a pillar of CSR. Research on CSR and environmental sustainability in the management literature is converging because of shared environmental, economic, and social concerns.

Avoiding and reducing sports-related environmental damage, the active involvement of those who pursue sports activities is neccessary.

It was interested to analyze RM's and BVB's responsible activity. Both clubs really take care of the society. They support foundations, schools, sport programs, they donate people, who are underprivileged, which can demonstrate clubs' social utility in their opinion. We can emphasize from the clubs' CSR activities the support of children as future generations trough education, sport or donation programs. Employees' health and well-being are also important for clubs.

In connection with environmental protection, reports, studies inform us about their long term targets, activities related to them and the achieved results. They try to do their best to reduce waste, cut energy, minimize water use those areas which are taken into consideration. They find it important to advise spectators, sponsors and suppliers about their activity and set a good example for the society.

\section{ACKNOWLEDGMENTS}

The publication is supported by the GINOP-2.3.2-15-2016-00062 project. The project is cofinanced by the European Union under the European Regional Development Fund.

\section{REFERENCES}

Blumrodt J., Desbordes M., Bodin D. (2013): Professional football clubs andcorporate social responsibility. Sport, Business and Management, 3(3): 205-225.

Brar R.S., Pathak A. (2016): Sports and environment. SOPAAN-II, 1(1): 7-11.

Business Council for Social Responsibility (BCSR) (2004): Introduction for CSR

Permanent link to this document: http://www.bsr.org/ BSRREsources/WhitPaperDetail.cfm?documentID $=48809$ Approached: October 2011.

BVB (2018): Shaping the future: Challenges and new beginnings at BVB. Sustainability Report for the 2017/2018 season. 78-104.

Campell M. (2018): German Bundesliga in focus. Permanent link to this document: https://sportsustainabilityjournal.com/ analysis/german-bundesliga-in-focus/ Approached: February 2019.

Carroll A.B. (1979): A three-dimensional conceptual model of corporate performance. Academy of Management Review,4(4): 497-505

Caroll A.B., Brown J.A. (2018): Corporate Social Responsibility: A Review of Current Concepts, Research and Issues. In Weber J., Wasleleski D. editors. Corporate Social Responsibility. U.K. Emerald Publishing Co., Chapter 2, 2018: 39-69.

Costa T. (2017): Corporate social responsibility within professional football clubs: an international multiple case study. Master degree. University of Gothenburg. 15-24.

Davies S.E.H., Moyo T. (2017): Community perceptions of a csr programme: a case study of a professional football club. Corporate Ownership\&Control, 14(3): 197-203.

Deng W., Zhou J. (2017): Analysis on Sports and Environmental Protection Problems. Permanent link to this document: http://dpi-proceedings.com/index.php/dteees/article/ viewFile/7859/7435 Approached: February, 2019.

Djaballah M., Hautbois C., Desbordes M. (2016): Sponsors'CSR strategies in sport: A sense making approach of corporations established in France. Sport Management Review, 20(2) 30.

Dowling M., Robinson L., Washington M. (2013): Taking advantage of the London 2012 Olympic Games: Corporate social responsibility through sport partnerships. European Sport Management Quarterly, 13(3): 269-292.

Esterluss K. (2017): How green is your soccer match beer cup? Permanent link to this document: https://www.dw.com/en/how- 
green-is-your-soccer-match-beer-cup/a-39730906 Approached: February, 2019.

European Commission (2001): Promoting a European framework for corporate social responsibility: Green Paper. Office for Official Publications of the European Communities, Luxembourg.

Filizöz B., Fisne M. (2011): Corporate Social Responsibility: A Study of Striking Corporate Social Responsibility Practices in Sport Management. Procedia Social and Behavioural Sciences, 24: 1405-1417.

Flöter T., Benkenstein M., Uhrich S. (2016): Communicating CSR-linked sponsorship: Examining the influence of three different types of message sources. Sport Management Review, 19(2): 146-156.

Giulianotti R., Darnell S., Collison H., Howe P.D. (2018): Sport for development and peace and the environment: The case for policy, practice, and research. Sustainability, 10(7): 2241.

Hegelow T. (2015): CSR in Professional Football - What are the Differences of Bundesliga Clubs towards Social Commitment - A Qualitative Analysis of Borussia Dortmund and VfL Wolfsburg. University of Twente. 7-10.

Huang H-C., Lin T-H., Lai M-C., Lin T-L. (2014): Environmental consciousness and green customer behavior: Anexamination of motivation crowding effect. International Journal of Hospitality Management, 40: 139-149.

Inoue Y., Kent A., Lee S. (2011): CSR and the Bottom Line: Analyzing the Link Between CSR and Financial Performance for Professional Teams. Journal of Sport Management, 25(6): 531-549.

Internet 1: Real Madrid Graduate School-Universidad Europea awarded the Copa Stadium National Sports Prize. Permanent link to this document: https://www.realmadrid.com/en/ news/2019/02/real-madrid-graduate-school-universidadeuropea-awarded-the-copa-stadium-national-sports-prize Approached: February 2019.

Internet 2: The new Real Madrid uniform is made with recycled plastic. Permanent link to this document: https:// latinamericanpost.com/22863-the-new-real-madrid-uniform-ismade-with-recycled-plastic Approached: February 2019.

Internet 3: Foundation projects - Spain Permanent link to this document: https://www.realmadrid.com/en/about-real-madrid/ foundation/projects/spain Approached: February 2019.

Internet 4: Real Madrid's Santiago Bernabeu given green light for upgrade. Permanent link to this document: https://www. bvb.de/eng/News/Foundation/New-BVB-training-program-forheavyweight-football-fans Approached: February 2019.
Internet 5: New BVB training program for heavyweight football fans. Permanent link to this document: https://www.thelocal. es/20180924/real-madrids-santiago-bernabeu-given-greenlight-for-upgrade Approached: February 2019.

Internet 6: "leuchte auf" funds playground equipment for primary school children. Permanent link to this document: https://www.bvb.de/eng/News/Foundation/leuchte-auffunds-playground-equipment-for-primary-school-children Approached: February 2019.

Internet 7: "leuchte auf" supports campaign for road traffic safety. Permanent link to this document: https://www.bvb. de/eng/News/Foundation/leuchte-auf-supports-campaign-forroad-traffic-safety Approached: February 2019.

Internet 8: Borussia Dortmund und Hermes Hansecontrol setzen erfolgreiche Zusammenarbeit fort. Permanent link to this document: https://newsroom.hermesworld.com/borussiadortmund-und-hermes-hansecontrol-setzen-erfolgreichezusammenarbeit-fort-6546/ Approached: February 2019.

Jenkins H. (2011): CSR in Sport: Investigating environmental sustainability in UK Premier League Football Clubs. Permanent link to this document: http://www.crrconference.org/Previous conferences/downloads/crrc2011jenkins.pdf Approached: August 2017.

Kolyperas D. G. (2012): Corporate and social responsibility in professional football club organizations. $\mathrm{PhD}$ dissertation. The University of Stirling. 20-55.

Moghaddam K.S., Abadi B.H., Eydi H. (2018): Investigating Environmental Responsibilities Involved in Sport Organizations. International Journal of Sports Science, 8(4): 109-117.

Nilsson L. (2018): CSR in Swedish football - A multiple case study of fourclubsin Allsvenskan. Master degree. Södertörn University. 10-20.

Papaspyropoulos K. P., Blioumis V., Christodoulou A. S., Birtsas P. K., Skordas K. E. (2012): Challenges in implementing environmental management accounting tools: the case of a nonprofit forestry organization. Journal of Cleaner Production, 29-30: 132-143.

Porter M.E., Kramer M.R. (2006): Strategy and society: the link between competitive advantage and corporate social responsibility. Harvard Business Review, 84: 78-92.

Ráthonyi-Odor K., Ráthonyi G. (2016): Környezetvédelmi kihívások a sportban. Journal of Central European Green Innovation, 4(2): 103-119.

Ráthonyi-Odor K., Ráthonyi G., Borbély A. (2016): Sportolni jó - felelôsen a sport népszerúsítéséért. ACTA - Agrártudományi Közlemények, Acta Agraria Debreceniensis, 67: 71-76. 
Real Madrid C. F. (2018): Corporate Social Responsibility and Sustainability Report 2017-2018, Madrid, 1-34.

Robert J., Delhez G. (2015): The Social Responsibility of Football Clubs: The 'Shared Value' as a Process of Value Creation? SSRN Electronic Journal. 2-3.

Scheinbaum A. C., Lacey R. (2015): Event social responsibility: A note to improve outcomes for sponsors and events. Journal of Business Research, 68: 1982-1986.

Shiply M. (2018): Sport and environment. Permanent link to this document:https://www.progressiveteacher.in/sport-andenvironment/ Approached: February 2019.

Smith A.C.T., Westerbeek H.M. (2007): Sport as a Vehicle for Deploying Corporate Social Responsibility. Journal of Corporate Citizenship, 25(12): 43-54.

Trendafilova S., Babiak K., Heinze K. (2013): Corporate social responsibility and environmental sustainability: Why professional sport is greening the playing field. Sport Management Review, 16: 298-313.

Trendafilova S., McCullough B., Pfahl M., Nguyen S.N., Casper J., Picariello M. (2014): Environmental sustainability in sport: Current state and future trends. Global Journal on Advances in Pure \& Applied Sciences, 3: 09-14.

Watson I., Prevos P. (2009): Milton Friedman on Corporate Social Responsibility Permanent link to this document: https://lucidmanager.org/milton-friedman-corporate-socialresponsibility/ Approached: February 2019.

World Business Council for Sustainable Development (2002): Corporate Social Responsibility: The WBCSD's Journey. World Business Council for Sustainable Development, ConchesGeneva, Switzerland. 
